\title{
STUDIES ON THE GLACIAL REFUGIA OF FOREST TREES ON BALKAN PENINSULA
}

\author{
Petar Zhelev \\ University of Forestry, Sofia, Bulgaria \\ e-mail: zhelev@ltu.bg
}

During the Ice Age the southern parts of Europe, including Balkans, remained practically unaffected by glaciations and served as refugia for many plant and animal species. However, even within the framework of each glacial refugia, the conditions were not homogeneous and isolated "hot spots" appeared that had led to "refugia within refugia". The territory of Balkan Peninsula could be subdivided into different zones, which are of different importance from the point of view of formation of the present day biodiversity. Tree species are particularly suitable for studies of inter-glacial and post-glacial migrations, due to their important ecological role in shaping the environmental conditions. Today, studying of these issues is greatly facilitated by introducing of genetic markers, allowing precise tracing of post-glacial migrations. The topic is less studied in the Balkan Peninsula, even though the region is considered one of the most important European refugia. A brief review of the more important studies in this respect is presented and the prospects and importance of such studies is discussed.

Key words: glacial refugia; Balkans; forest trees; genetic markers; migrations

\section{INTRODUCTION}

The glacial refugia are considered safe havens [1], where biota survived periods of glaciation during the Last Glacial Maximum (LGM) in Europe - until 12000 before present [2]. During the glaciations, Northern and part of Central Europe were covered by glaciers, up to several $\mathrm{km}$ thick, which had caused extinction of all plant species and extinction or migration of the animal species. At the same time, in the southern parts of the continent, and in the Balkan Peninsula in general, most of area was ice free, which allowed most species to survive in favourable habitats without the need to migrate latitudinally; however, elevational range shifts were detected. The three southern peninsulas (Iberian, Italian and Balkan) are considered the three main glacial refugia in Europe [3]. The terminology related to glacial refugia is rather complicated, particularly due to the new scientific achievements during the last decades. Palaeorefugia, neorefugia, macro- and microrefugia, in situ and ex situ refugia and many others have been defined [4-6], for review see [7]. The term "refugium" was originally used to describe the restricted full-glacial locations of modern mid- and highlatitude taxa, especially trees and shrubs, but gained later a wider meaning [8].

According to Kutzbach and Guetter [9], during the LGM the mean temperature in July on the Balkan Peninsula and in Bulgaria, in particular, was about $5{ }^{\circ} \mathrm{C}$ lower than today and there was almost no ice cover [10-12]. In that period, the highest diversity did not exist at the lowest altitude (with the highest temperature), but at the middle altitude, due to the highest air humidity [13]. The peculiarities and importance of Balkan Peninsula as a glacial refugium and a high biodiversity centre have been evaluated accordingly $[14,15]$.

After the glacial retreat, a process of recolonization started. The recolonization of the lands that were ice-scraped until recently is a part of a more general process of postglacial migrations, including not only recolonization of the new territories, but 
also moving the species into different directions as a result of the climate change and specific regional environmental conditions. The main centres in $\mathrm{Eu}-$ rope where the recolonization started were the three glacial refugia in the three southern peninsulas. However, more detailed studies have shown that glacial refugia, albeit of modest size, existed also in more northern localities, mostly southward from Alps (e.g. in the present-day Slovenia) and from Northern Carpathians (Hungary and Slovakia).

\section{FOREST TREES AS MODEL SPECIES}

Large part of the studies on the postglacial migrations use the forest trees as model species. This is due to several reasons. First, many of tree species cover large areas and have a well expressed role in the formation of environmental conditions. A total of 24 taxa - genera and species - were reported for southern European refugia, based on macrofossil or reliable pollen evidence [16]. This is important also because the forests are habitat of many other living organisms. Second, many tree species (all conifers, species of genera Quercus, Fagus, Carpinus, Ulmus, Populus and some others) are anemophilous (wind-pollinated). They produce large quantity of pollen, which is accumulated in peat bogs, lakes and other similar places and therefore, these species are very suitable for palynological studies. Third, plant macrofossils of tree species are much more common than such of other plant life forms.

In the context of the general trend that recolonization of the northern parts of Europe started from the southern refugia and was moving northward, the hypothesis aroused that the highest intraspecific genetic diversity should be expected in the glacial refugia. However, the studies of 22 arboreal species have shown that the picture is much more complicated and the genetically most diverse populations were not located in the south, but at intermediate latitudes [3]. This can be explained first, as a consequence of the admixture of divergent lineages colonizing the continent from separate refugia, and second, with admixture of the main recolonization routes with more northern ones, even coming from smaller refugia $[3,9]$. The last studies showed that glacial refugia for tree species existed northward from the Alps, although patchily distributed at low densities due to low atmospheric $\mathrm{CO}_{2}$ concentrations and high wind-speeds $[17,18]$.

Both now and during the glaciations the climatic conditions in the large glacial refugia differ dramatically both in the ecological variables (temperature, humidity, soil conditions etc.), and in some specific conditions, which were important from the aspect of survival of the species. Therefore, smaller regions could be identified in the framework of the large glacial refugia, and these regions represents "hot spots" for some species or group of species (the different "traces" of these species - genetic, paleobotanical - are the most numerous there). These "hot spots" were called "refugia within refugia". Their identification and localization in the tree species are based on the geographical distribution of genetic diversity corroborated by palynological data. Unique genetic diversity can be observed in glacial refugia through modern genetic markers, based on DNA analysis, that allow comparatively fast and routine estimation of the level and distribution of genetic diversity.

Existing of "refugia within refugia" called hereafter "small refugia" shows that the glacial refugia are structured and not homogeneous. During the glaciations, different environmental factors had been combined in an optimal way for some species or group of species and thus small refugia were formed.

The structuring within the refugia has been reported for different species in different geographic regions [19-23].

Nieto Feliner stated that speaking of a single refugium to refer to each of the peninsulas, howev$\mathrm{er}$, is an oversimplification [24]. Even speaking of multiple unconnected refugia does not adequately reflect the complexity of the processes that shaped the current genetic and specific diversity.

Even though the concept of southern peninsulas as the only glacial refugia was revised, they still provoke considerable attention, due to their size. As mentioned above, extra-Mediterranean refugia were smaller by and of smaller importance [17]. The southern refugia are presented in detail in the monograph of Weiss and Ferrand [25].

\section{STUDIES ON THE REFUGIA OF FOREST TREES IN BALKANS}

In the southern Balkans many temperate tree species survived the Quaternary climatic oscillations in isolated habitats which had particular microclimatic conditions [26]. The topographic variability of the Balkans and its long-term environmental stability may have played a major role in facilitating strong genetic differentiation on a small geographic scale [27, 28]. Growing evidence from phylogeographic studies of animal [28, 29] and plant species $[30,31]$ suggest that there were multiple Pleistocene microrefugia within the Balkans. 
The phylogeographic studies in tree species were enhanced to a greater extent by introducing the new generation of DNA-based genetic markers. Particularly useful proved to be chloroplast DNA (cpDNA) and mitochondrial DNA (mtDNA), which are extranuclear markers and are in most cases uniparentally inherited. Usually cpDNA is maternally inherited in most Angiosperms and paternally in Gymnosperms, while mtDNA is maternally inherited in Angiosperms and most of Gymnosperms, but paternally inherited in Taxodiaceae and Cupressaceae [32]. When the mode of inheritance of cytoplasmic DNA is known, this allows tracing relatively easily the migration routes by employing the proper genetic marker. Cytoplasmic DNA markers are frequently referred to as haplotypes. There was vast amount of studies using such markers in phylogeographic studies in Europe, including tree species (see [33] for references)

The tree species on Balkan Peninsula, in particular, were studied to a lesser extent, as compared with these in Western and Central Europe. The studies, however, confirmed the structuring of this refugium. Ballian et al. [34] detected separation of the Croatian silver fir (Abies alba Mill.) populations from the group of the eastward situated ones, which can be explained at least partly by existence of different glacial refugia. Multiple refugia were found for the same species in other studies $[35,36]$ and the contemporary map of genepool distribution is complicated additionally by the existence of suture zones and introgressive hybridization [37]. Existing of multiple refugia is not unprecedented in this species, as reported also for Iberian Peninsula [38].

Similar trends were observed also in other conifer species - genetic diversity in Pinus sylvestris $\mathrm{L}$. was the highest in Balkans suggesting existence of at least one refugium $[39,40]$ similarly like Pinus nigra J. F. Arnold [41].

European beech (Fagus sylvatica L.) was one of most extensively studied species due to its large distribution and economic importance. Magri et al. [42] corrected the previous concepts and proved that the species survived in multiple refugia. Even though the Balkan refugia were separated from the central European ones and did not contribute to the colonization of the land northern from the peninsula, the haplotype diversity here was the highest, with several different haplotypes, indicating existence of several micro-refugia. Micro-refugia were detected also Fraxinus excelsior L. and Fraxinus angustifolia Vahl. [43, 44]

Oaks (Quercus spp.) received particular attention, including on Balkans. At least two lineages were identified by Bordács et al. [45] - one to the east of the Carpathian Mountains in Romania [46], and another - coming from the south. However, the southern and eastern part of the peninsula were underrepresented in this study. Recently, multiple refugia were found for most of white oaks in Balkans within a bilateral project Romania-Bulgaria [47].

Three small refugia in Balkan Peninsula were identified in Turkey oak (Quercus cerris L.), and even the populations from the eastern and western part of a relatively small region like Bulgaria clearly differed from each other in their genetic constitution, as determined by cpDNA haplotypes (see Figure 1 in [48]).

In a study on the European hornbeam (Carpinus betulus L.) Postolache et al. [49] found that its evolution, glacial and post-glacial migrations followed the scenario "refugia within refugia" (Figure 1). The results of the study revealed the significant expansion of $C$. betulus, still before the common beech (Fagus sylvatica L.). This major expansion is considered to be a major particularity in Holocene postglacial evolution of forests from the Romanian Carpathians and the Bulgarian Black Sea coastal zone, which was in concordance with the results of palynological studies [50, 51]. The hornbeam's postglacial evolution in the Carpathians and Balkan Peninsula was different from that in the Western Europe.

All these studies need palaeobotanical information, which is available for different periods and for different regions of Bulgaria and Balkan Peninsula [52-55].

The brief review illustrates that Balkan Peninsula is still not studied in sufficient extent, given the opportunities it provides, as harbouring one of the richest genepool of many different groups of living organisms, and particularly, tree species. Studies on the phylogeography and structure of the glacial refugia on the peninsula will be highly relevant and timely. Such studies possess an interest both from fundamental and applied point of view. Also, they are of international interest and provide good opportunity for cooperation of researchers from the different Balkan countries, and being interdisciplinary - from different research areas, too.

Acknowledgments. The author thanks Dragos Postolache and Flaviu Popescu (National Research and Development Institute "Marin Dracea" - Romania) for their cooperation and help, and to two anonymous reviewers for their suggestions for improving the final draft of the manuscript. Also, the permission of ELSEVIER to re-publish Figure 5 of the article of Postolache et al. (2017) published in the journal Science of the Total Environment, vol. 599-600, pp. 1492-1502, is very much appreciated. 


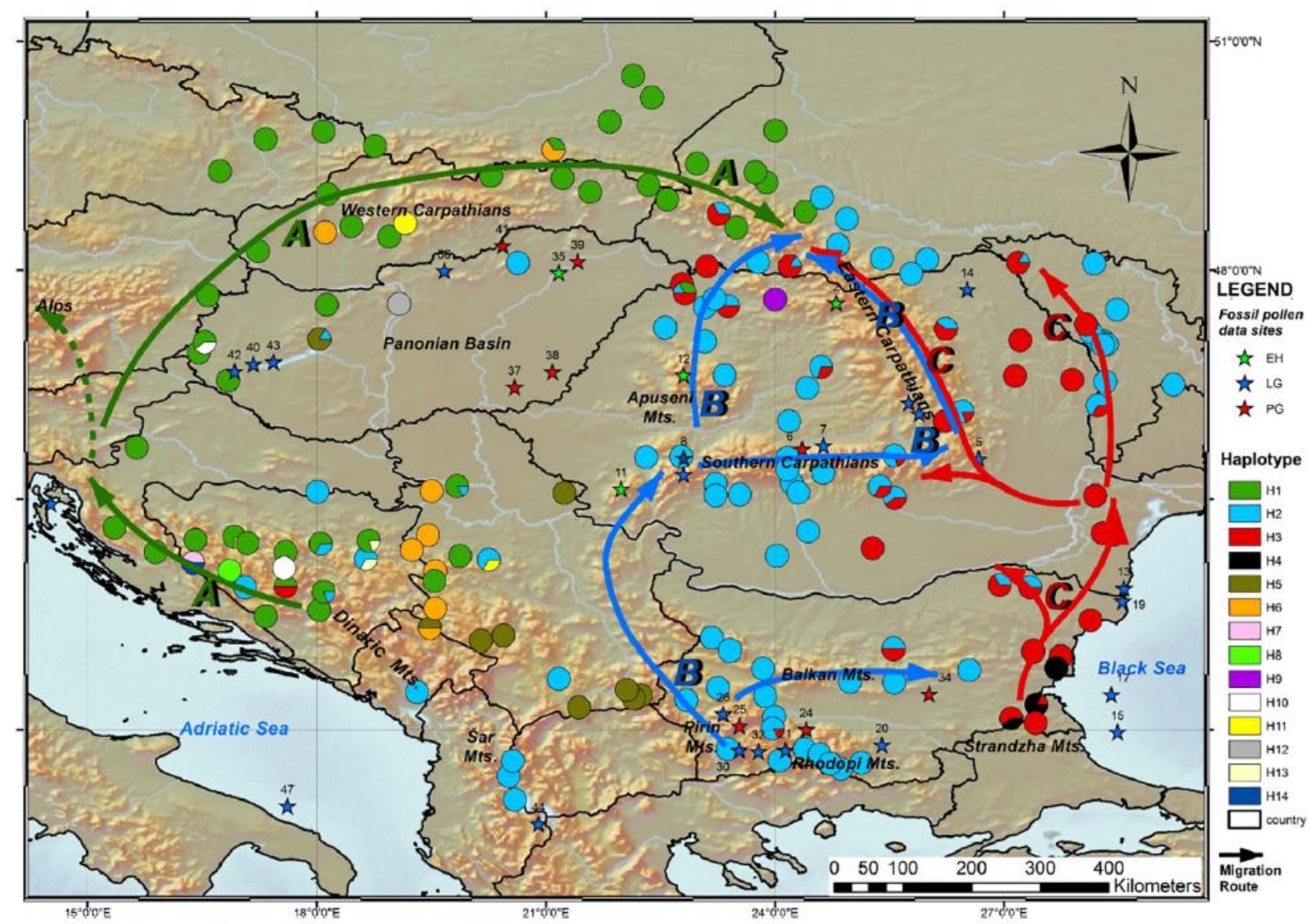

Figure 1. Post-glacial re-colonization routes of Carpinus betulus based on chloroplast DNA haplotypes $(\mathrm{H})$ and fossil pollen data. Arrowed lines show potential post-glacial re-colonization routes (route A, route B and route C). Stars number indicates pollen sites with $C$. betulus records from Quaternary periods: EH (green star) from Early Holocene, LG (blue star) from Late Glacial, PG (red star) from Pleniglacial.

(Reprinted from: Forest Ecology and Management, Vol. 599-600. D. Postolache, F. Popescu, L. Paule, D. Ballian, P. Zhelev, S. Fărcaş, J. Paule and O. Badea. Unique postglacial evolution of the hornbeam (Carpinus betulus L.) in the Carpathians and the Balkan Peninsula revealed by chloroplast DNA, pages 1493-1502, Copyright (2017), with permission from Elsevier)

\section{REFERENCES}

[1] G. Keppel, K. P. Van Niel, G. W. WardellJohnson, C. J. Yates, M. Byrne, L. Mucina, A. G. T. Schut, S. D. Hopper, S. E. Franklin, Refugia: identifying and understanding safe havens for biodiversity under climate change, Glob. Eco. Biogeo., 21 (2012), pp. 393-404.

[2] A. Mackintosh, N. Golledge, E. Domack, R. Dunbar, A. Leventer, D. White, D. Pollard, R. DeConto, D. Fink, D. Zwartz, D. Gore, C. Lavoie, Retreat of the East Antarctic ice sheet during the last glacial termination, Nat. Geosci., 4 (2011), pp. 195-202.

[3] R. J. Petit, I. Aguinagalde, J.-L. de Beaulieu, C. Bittkau, S. Brewer, R. Cheddadi, R. Ennos, S. Fineschi, D. Grivet, M. Lascoux, A. Mohanty, G. Müller-Starck, B. Demesure-Musch, A. Palmé, J. P. Martín, S. Rendell, G. G. Vendramin, Glacial refugia: hotspots but not melting pots of genetic diversity, Science, 300 (5625) (2003), pp. 15631565 .
[4] J. C. Nekola, Paleorefugia and neorefugia: the influence of colonization history on community pattern and process, Ecology, 80 (1999), pp. 24592473.

[5] V. Rull, Microrefugia, J. Biogeog., 36 (2009), pp. 481-484.

[6] R. Holderegger, C. Thiel-Egenter, A discussion of different types of glacial refugia used in mountain biogeography and phylogeography, J. Biogeog., 36 (2009), pp. 476-480.

[7] P. C. Tzedakis, B. C. Emerson, G. M. Hewitt, Cryptic or mystic? Glacial tree refugia in northern Europe, Trends in Ecology and Evolution, 28 (2013), pp. 696-704.

[8] K. D. Bennett, J. Provan, What do we mean by 'refugia'? Quat. Sci. Rev., 27 (2008), pp. 24492455.

[9] J. E. Kutzbach, P. J. Guetter, The influence of changing orbital parameters and surface boundary conditions on climate simulations for the past 
18,000 years, J. Atm. Sci., 43 (1986), pp. 17261759 .

[10] J. Thiede, Glacial Mediterranean, Nature, 276 (1974), pp. 680-683.

[11] G. H. Denton, T. J. Hughes, The Last Great Ice Sheets, Willey, N.Y., 1981.

[12] A. G. Dawson, Ice Age Earth: Late Quaternary Geology and Climate, Routledge, London, 1992.

[13] K. J. Willis, The vegetation history of the Balkans, Quat. Sci. Rev., 13 (1994), pp. 769-778.

[14] H. I. Griffiths, B. Krystufek, J. M. Reed (Eds), Balkan Biodiversity: Pattern and Process in the European Hotspot, Springer, Dordrecht, 2004.

[15] P. Zhelev (Ed), Balkans - Hot Spots of Ancient and Present Genetic Diversity, International Scientific Conference, Sofia, Book of Abstracts, 2009.

[16] H. J. B. Birks, K. Willis, Alpines, trees, and refugia in Europe, Plant Ecology \& Diversity, 1 (2008), pp. 147-160.

[17] J.-C. Svenning, S. Normand, M. Kageyama, Glacial refugia of temperate trees in Europe: insights from species distribution modelling, J. Eco., 96 (2008), pp. 1117-1127.

[18] T. Schmitt, Z. Varga, Extra-Mediterranean refugia: The rule and not the exception? Front. Zoo., 9 (2012), pp. 22.

[19] P. Abellán, J.-C. Svenning, Refugia within refugia - patterns in endemism and genetic divergence are linked to Late Quaternary climate stability in the Iberian Peninsula, Bio. J. Lin. Soci., 113 (2014), pp. 13-28.

[20] P. Alexandri, A. Triantafyllidis, S. Papakostas, E. Chatzinikos, P. Platis, N. Papageorgiou, G. Larson, T. J.Abatzopoulos, C. Triantaphyllidis, The Balkans and the colonization of Europe: the post-glacial range expansion of the wild boar, Sus scrofa, J. Biogeogr., 39 (2012), pp. 713-723.

[21] R. Brus, Growing evidence for the existence of glacial refugia of European beech (Fagus sylvatica L.) in the south-eastern Alps and north-western Dinaric Alps, Periodicum Biologorum, 112 (2010), pp. 239-246.

[22] A. Fijarczyk, K. Nadachowska, S. Hofman, S.N. Litvinchuk, W. Babik, M. Stuglik, G. Gollmann, L. Choleva, D. Cogalniceanu, T. Vukov, G. Dzukic, J. M. Szymura, Nuclear and mitochondrial phylogeography of the European fire-bellied toads Bombina bombina and Bombina variegata supports their independent histories, Mol. Eco, 20 (2011), pp. 3381-3398.

[23] F. Stefani, A. Gentilli, R. Sacchi, E. Razzetti, D. Pellitteri-Rosa, F. Pupin, P. Galli, Refugia within refugia as a key to disentangle the genetic pattern of a highly variable species: The case of Rana temporaria Linnaeus, 1758 (Anura, Ranidae), Mol. Phylo. Evolu., 65 (2012), pp. 718-726.
[24] G. Nieto Feliner, Southern European glacial refugia: A tale of tales, Taxon, 60 (2011), pp. 365-372.

[25] S. Weiss, N. Ferrand (Eds), Phylogeography of Southern European Refugia. Springer, Dordrecht, The Netherlands, 2007.

[26] P. Tzedakis, The Balkans as prime glacial refugial territory of European temperate trees, In: Balkan Biodiversity, Pattern and Process in the European Hotspot, H. I. Griffiths, B. Kryštufek, J. M. Reed (Eds), Springer, Dordrecht, 2004, pp. 49-68.

[27] J. Aleksić, A. Piotti, T. Geburek, G. G. Vendramin, Exploring and conserving a "microcosm": whole-population genetic characterization within a refugial area of the endemic, relict conifer Picea omorika, Cons. Gen., 18 (2017), pp. 777-788.

[28] B. Krystufek, E. V. Buzan, W. F. Hutchinson, B. Hänfling, Phylogeography of the rare Balkan endemic Martino's vole, Dinaromys bogdanovi, reveals strong differentiation within the western Balkan Peninsula, Mol. Eco., 16 (2007), pp. 12211232.

[29] M. Podnar, W. Mayer, N. Tvrtković, Mitochondrial phylogeography of the Dalmatian wall lizard, Podarcis melisellensis (Lacertidae), Org. Div. Evol, 4 (2004), pp. 307-317.

[30] D. Kutnjak, M. Kuttner, M. Niketić, S. Dullinger, P. Schönswetter, B. Frajman, Escaping to the summits: phylogeography and predicted range dynamics of Cerastium dinaricum, an endangered high mountain plant endemic to the western Balkan Peninsula. Mol. Phylo. Evol., 78 (2014), pp. 365-374.

[31] B. Surina, P. Schönswetter, G. M. Schneeweiss, Quaternary range dynamics of ecologically divergent species (Edraianthus serpyllifolius and $E$. tenuifolius, Campanulaceae) within the Balkan refugium, J. Biogeog., 38 (2011), pp. 1381-1393.

[32] T. L. White, W. T. Adams, D. B. Neale, Forest Genetics, CABI Publishing, 2007.

[33] R. J. Petit, G. G. Vendramin, Plant phylogeography based on organelle genes: An introduction. In: Phylogeography of Southern European Refugia, S. Weiss, N. Ferrand (Eds), Springer, Dordrecht, The Netherlands, 2007, pp. 23-97.

[34] D. Ballian, F. Bogunić, M. Bajrić, D. Kajba, H. Kraigher, M. Konnert, The genetic population study of Balkan silver fir (Abies alba Mill.), Periodicum Biologorum, 114 (2012), pp. 55-65.

[35] D. Gömöry, R. Longauer, S. Liepelt, D. Ballian, R. Brus, H. Kraigher, V. I. Parpan, T. V. Parpan, L. Paule, V. I. Stupar, B. Ziegenhagen, Variation patterns of mitochondrial DNA of Abies alba Mill. in suture zones of postglacial migration in Europe. Acta Soc. Bot. Polo., 73 (2004), pp. 203-206.

[36] S. Liepelt, R. Cheddadi, J.-L. de Beaulieu, B. Fady, D. Gömöry, E. Hussendörfer, M. Konnert, T. Litt, R. Longauer, R. Terhürne-Berson, B. Zieg- 
enhagen, Postglacial range expansion and its genetic imprints in Abies alba (Mill.) - a synthesis from palaeobotanic and genetic data, Review of Palaeobotany and Palynology, 153 (2009), pp. 139-149.

[37] D. Krajmerová, L. Paule, P. Zhelev, M. Voleková, I. Evtimov, V. Gagov, D. Gömöry, Natural hybridization in eastern-Mediterranean firs: The case of Abies borisii-regis, Plant Biosyst., 150 (2016), pp. 1189-1199.

[38] A. Piotti, C. Leonarduzzi, D. Postolache, F. Bagnoli, I. Spanu, L. Brousseau, C. Urbinati, S. Leonardi, G. G. Vendramin, Unexpected scenarios from Mediterranean refugial areas: disentangling complex demographic dynamics along the Apennine distribution of silver fir, J. Biogeog, 44 (2017), pp. 1547-1558.

[39] A. L. Curtu, W. Prus-Głowacki, L. Urbaniak, E. Bujasa, Genetic variation of isolated and peripheral populations of Pinus sylvestris (L.) from glacial refugia, Flora, 207 (2012), pp. 150-158.

[40] K. Naydenov, S. Senneville, J. Beaulieu, F. Tremblay, J. Bousquet, Glacial vicariance in Eurasia: mitochondrial DNA evidence from Scots pine for a complex heritage involving genetically distinct refugia at mid-northern latitudes and in Asia Minor, BMC Evoutionary Biology, 7 (2007), p. 233.

[41] Z. Šarac, T. Dodoš, N. Rajčević, S. Bojović, P.D. Marin, J.M. Aleksić, Genetic patterns in Pinus nigra from the central Balkans inferred from plastid and mitochondrial data, Silva Fennica, 49 (2015), article id 1415, 12 p.

[42] D. Magri, G. G. Vendramin, B. Comps, I. Dupanloup, T. Geburek, D. Gömöry, M. Latałowa, T. Litt, L. Paule, J. M. Roure, I. Tantau, W. O. Van Der Knaap, R. J. Petit, J.-L. De Beaulieu, A new scenario for the Quaternary history of European beech populations: palaeobotanical evidence and genetic consequences, New Phytologist, 171 (2006), pp. 199-221.

[43] M. Heuertz, S. Fineschi, M. Anzidei, R. Pastorelli, D. Salvini, L. Paule, N. Frascaria-Lacoste, O. J. Hardy, X. Vekemans, G. G. Vendramin, Chloroplast DNA variation and postglacial recolonization of common ash (Fraxinus excelsior L.) in Europe, Mol. Eco., 13 (2004), pp. 3437-3452.

[44] M. Temunović, N. Frascaria-Lacoste, J. Franjić, Z. Satovic, J. F. Fernández-Manjarrés, Identifying refugia from climate change using coupled ecological and genetic data in a transitional Mediterranean-temperate tree species, Mol. Eco., 22 (2013), pp. 2128-2142.

[45] S. Bordács, F. Popescu, D. Slade, U. M. Csaikl, I. Lesur, A. Borovics, P. Kézdy, A. O. König, D. Gömöry, S. Brewer, K. Burg, R. J. Petit, Chloroplast DNA variation of white oaks in northern
Balkans and in the Carpathian Basin, Forest Ecology and Management, 156 (2002), pp. 197-209.

[46] I. C. Moldovan, N. Sofletea, A. L. Curtu, I. V. Abrudan, D. Postolache, F. Popescu, Chloroplast DNA diversity of oak species in Eastern Romania. Notulae Botanicae Horti Agrobotanici ClujNapoca, 38 (2010), pp. 302-307.

[47] D. Postolache, F. Popescu, P. Zhelev, Creating of synthetic geographic maps of distribution of the modern genetic diversity and post-glacial history of Quercus and Carpinus species in Romania and Bulgaria. Unpublished report of a bilateral research project, Bucharest-Sofia, 2012.

[48] F. Bagnoli, Y. Tsuda, S. Fineschi, P. Bruschi, D. Magri, P. Zhelev, L. Paule, M.C. Simeone, S.C. González-Martínez, G.G. Vendramin, Combining molecular and fossil data to infer demographic history of Quercus cerris: insights on European eastern glacial refugia, J. Biogeog., 43 (2016), pp. 679-690.

[49] D. Postolache, F. Popescu, L. Paule, D. Ballian, P. Zhelev, S. Fărcaş, J. Paule, O. Badea, Unique postglacial evolution of the hornbeam (Carpinus betulus L.) in the Carpathians and the Balkan Peninsula revealed by chloroplast DNA, Sci. Tot. Environ., 599-600 (2017), pp. 1493-1502.

[50] M. Filipova-Marinova, Postglacial vegetation dynamics in the coastal part of the Strandzha Mountains, Southeastern Bulgaria, in: Aspects of Palynology and Palaeoecology: Festschrift in Honour of Elissaveta Bozilova, S. Tonkov (Ed), Pensoft Publishers, Sofia and Moscow, 2003, pp. 213-231.

[51] M. Filipova-Marinova, D. Pavlov, M. Coolen, L.Giosan, First high-resolution marino palynological stratigraphy of late quaternary sediments from the central part of the Bulgarian Black Sea area. Quat. Inter., 293 (2013), pp. 170-183.

[52] V. S. Bozukov, B. V. Tsenov, Catalogue of the Cenozoic plants of Bulgaria (Eocene to Pliocene) Addendum and Corrigendum. Phyto. Balcan., 18 (2012), pp. 237-261.

[53] S. Tonkov, M. Lazarova, E. Bozilova, D. Ivanov, I. Snowball, A 30,000-year pollen record from Mire Kupena, Western Rhodopes Mountains (south Bulgaria). Review of Palaeobotany and Palynology, 209 (2014), pp. 41-51.

[54] M. A. Lazarova, E. Marinova, S. Tonkov, I. F. Snowball, A 5000-year pollen and plant macrofossil record from the Osogovo Mountain, Southwestern Bulgaria: Vegetation history and human impact. Review of Palaeobotany and Palynology, 223 (2015), pp. 1-9.

[55] W. Finsinger, C. Morales-Molino, M. Gałka, V. Valsecchi, S. Bojovic, W. Tinner, Holocene vegetation and fire dynamics at Crveni Potok, a small mire in the Dinaric Alps (Tara National Park, Serbia). Quat. Sci. Rev., 167 (2017), pp. 63-77. 


\title{
СТУДИИ ЗА ГЛАЦИЈАЛНИ РЕФУГИУМИ НА ШУМСКИ ДРВЈА НА БАЛКАНСКИОТ ПОЛУОСТРОВ
}

\author{
Petar Zhelev
}

University of Forestry, Sofia, Bulgaria

\begin{abstract}
Во леденото време јужните делови на Европа, вклучувајќи го и Балканот, не биле погодени од глечерите и служеа како засолниште за многу растителни и животински видови. Сепак, дури и во рамките на секој глацијален рефугиум, условите не биле хомогени и се појавиле изолирани „потопли места“, што довело до ,рефугиум во рамките на рефугиумот“. Територијата на Балканскиот Полуостров може да се подели на различни зони, кои се од различна важност од аспект на формирањето на денешната биолошка разновидност. Видовите дрвја се особено погодни за испитување на интерглацијалните и постглацијалните миграции поради нивната важна еколошка улога во обликувањето на еколошките услови. Денес проучувањето на овие прашања во голема мера е олеснето со воведувањето на генетски маркери, кои овозможуваат прецизно следење на постглацијалните миграции. На Балканскиот Полуостров темата помалку се изучува, иако регионот се смета за еден од најважните европски рефугиуми. Презентиран е краток преглед на поважните студии на оваа тема и се разгледуваат перспективата и значењето на ваквите испитувања.
\end{abstract}

Клучни зборови: глацијални рефугии; Балкан; шумски дрвја; генетски маркери; миграции 